This item was submitted to Loughborough's Research Repository by the author.

Items in Figshare are protected by copyright, with all rights reserved, unless otherwise indicated.

\title{
Cultural foundations of corporate control: an empirical enquiry [Abstract]
}

PLEASE CITE THE PUBLISHED VERSION

PUBLISHER

(C) Academy of Management

VERSION

AM (Accepted Manuscript)

PUBLISHER STATEMENT

This paper was accepted for publication in the journal Academy of Management Proceedings and the definitive published version is available at https://doi.org/10.5465/AMBPP.2017.13524abstract.

LICENCE

CC BY-NC-ND 4.0

\section{REPOSITORY RECORD}

Bayat, Ali, and Peter Kawalek. 2019. "Cultural Foundations of Corporate Control: An Empirical Enquiry [abstract]". figshare. https://hdl.handle.net/2134/27003. 


\title{
Cultural Foundations of Corporate Control: An Empirical Enquiry
}

\author{
Ali Bayat, Peter Kawalek \\ Alliance Manchester Business School
}

\begin{abstract}
This paper argues for the importance of culture for corporate governance practices. We utilise both the contemporary and early patterns in settlement of Scots-Irish in the United States to study the effect of honour culture on the defensive behaviour of target firms in corporate control contests. Honour culture is characterised by reputation maintenance and defence. We compare the behaviour of target firms in places with varying degree of honour culture. We empirically examine if firms located in places with an honour culture are more resistant to hostile takeovers when becoming a target. We find that these firms show more resistance to hostile takeovers when becoming a target, and are more likely to win the contests. Beyond the existing explanations for target firm resistance, this study sheds light on how cultural dynamics can shape takeover resistance and corporate control.
\end{abstract}

Keywords: Culture of Honour, Corporate Governance, Corporate Control, Hostile Takeovers, Takeover Resistance 